\title{
Kisah Cinta Tidak Indah : Studi Kekerasan dalam Relasi Pacaran Mahasiswa di Fakultas Ilmu Sosial dan Ilmu Politik Universitas Cenderawasih Jayapura
}

\author{
Fitrine Christianne Abidjulu', Rima Nusantriani Banurea \\ Universitas Cenderawasih
}

\begin{abstract}
Dating is a popular relationship among college students. In our expectation, dating becomes popular because it is fun. However, in reality, dating is tend to be unpleasure relationship. This can be occured because of violence. The existence of violence in dating has a strong relation with the understanding of love. Love is often misunderstood by people who are dating as a ownership and control. Therefore, the topic about how violence's manifest in dating relationships is important question. This research aims to look the relationship between college students in Faculty of Social and Political Sciences (FISIP) of Cenderawasih University, Jayapura, Papua. The results of this study are the concept of love are important to building (consciously or unconsciously) violent acts in dating relation. Then the culture and experience from both the victims and the perpretators are important to perpetuating violence. Furthermore, the general form of violence at least exists in 5 forms like psychological violence, physical violence, verbal violence, digital violence and financial violence.
\end{abstract}

Keywords : Violence in Dating, Perpetrator, Victim, Papua, Love, Control

\begin{abstract}
Abstrak
Relasi pacaran adalah relasi yang populer di kalangan mahasiswa. Pacaran menjadi relasi yang populer dikarenakan sifat pacaran yang seharusnya menjadi relasi menyenangkan. Namun, ternyata dalam realitas, pacaran adalah relasi yang rentan terhadap kekerasan. Hal ini berkaitan dengan pemahaman cinta dan sayang yang diterjemahkan sebagai kepemilikan dan terwujud dalam sikap-sikap kontrol. Oleh sebab itu menarik untuk melihat bagaimana KDP hadir dan mewujud dalam relasi pacaran. Penelitian ini secara khusus membidik relasi pacaran di kalangan mahasiswa di Fakultas Ilmu Sosial dan Ilmu Politik (FISIP) Universitas Cenderawasih Jayapura, Papua. Hasil dari penelitian ini adalah konsep cinta yang dianut pelaku dan korban berperan penting sebagai dasar dalam membangun (sadar atau tidak sadar) kekerasan hubungan pacaran. Kemudian budaya serta pengalaman korban dan pelaku berperan penting dalam melanggengkan kekerasan. Selanjutnya kekerasan setidaknya mewujud dalam lima bentuk yakni kekerasan psikis, kekerasan fisik, kekerasan verbal, kekerasan digital dan kekerasan finansial.
\end{abstract}

Kata Kunci : Kekerasan dalam Pacaran (KDP), Pelaku, Korban, Papua, Cinta, Kontrol

${ }^{1}$ fitrine@yahoo.com 
Kisah Cinta Tidak Indah : Studi Kekerasan dalam Relasi Pacaran Mahasiswa di Fakultas Ilmu Sosial dan Ilmu Politik Universitas Cenderawasih Jayapura

\section{Pendahuluan}

Pacaran seharusnya menjadi relasi menyenangkan bagi pihak yang terlibat. Namun realitas akhir-akhir ini menunjukkan relasi pacaran sangat rentan dengan kekerasan. Berdasarkan data Catatan Tahunan Komisi Nasional Perempuan, Kekerasan dalam Pacaran (KDP) adalah jenis Kekerasan Terhadap Perempuan (KTP) di ranah domestik/personal tertinggi kedua setelah Kekerasan Dalam Rumah Tangga (KDRT) dengan jumlah persentasi 21\% atau sebanyak 2.171 kasus (2017: p.22). Data ini tentu saja tidak bisa dianggap sebagai data akhir, karena sama seperti tipikal kekerasan lainnya, kasus-kasus KDP yang muncul ke permukaan hanyalah fenomena gunung es. Artinya masih banyak kasus KDP yang tidak terdeteksi karena korban tidak melapor atau bahkan yang lebih menyedihkan lagi, baik korban ataupun pelaku tidak merasa terjadi kekerasan di relasi mereka.

Sebelum lebih dalam membahas KDP, lebih bijaksana membahas kekerasan itu sendiri dahulu. Kekerasan menurut John Galtung adalah “... setiap kondisi fisik, emosional, verbal, institusional, struktural atau spiritual, juga perilaku, sikap, kebijakan atau kondisi yang melemahkan, mendominasi atau menghancurkan diri kita sendiri dan orang lain" (dalam Eriyanti 2017: p. 29). Oleh Galtung kekerasan dibedakan lagi menjadi kekerasan langsung, kekerasan struktural dan kekerasan kultural. Dalam konteks kekerasan dalam pacaran, kekerasan yang terjadi bersifat langsung, namun disebabkan oleh kekerasan struktural dan kekerasan kultural melalui patriarki (Eriyanti, 2017).

Kekerasan struktural ada dalam patriarki karena patriarki memposisikan laki-laki sebagai pihak dominan atau subjek sedangkan menempatkan perempuan dalam posisi subordinat atau objek. Dalam pengertian ini, penyebab kekerasan bukan karena pelaku yang jahat, melainkan struktur yang salah. Kemudian patriarki sebagai kekerasan kultural membentuk sikap, pemahaman hingga keyakinan bahwa dalam kehidupan sehari-hari manusia membutuhkan kekusaan dan kekerasan. Kekerasan kultural inilah yang kemudian membuat kekerasan langsung dan kekerasan struktural terlihat sebagai sesuatu yang benar (Eriyanti, 2017: p.33). 
KDP sendiri adalah perilaku, “....that is prejudicial to the partner's development or health by compromising his or her physical, psychological, or sexual integrity" (Lavoie, Robitaille, \& Hébert, 2000: p. 8 dalam Courtaina\&Glowaczb, 2019: p.2). Salah satu yang menjadi masalah utama terkait dengan KDP adalah baik pelaku maupun korban tidak sadar bahwa mereka melakukan kekerasan (Kim et al., 2019: p.47). Hal ini bisa terjadi karena pacaran merupakan relasi sosial yang memiliki ikatan moral antara laki-laki dan perempuan dengan alat integritas bernama cinta yang bertugas untuk memenuhi unsur kebersamaan (Sari, 2018: p.56).

Cinta ini kemudian membangun kedekatan dalam pacaran; membangun hubungan yang ekslusif sehingga menjustifikasi kontrol berlebihan pada pasangan. Selain itu, KDP disebabkan oleh konstruksi imajinasi pacaran yang berdasarkan pada kepemilikan. Bukti cinta adalah kepemilikan. Konsep kepemilikan inilah yang melegitimasi kekerasan dalam relasi pacaran (Sari, 2019:p.57).

Kepemilikan dalam pacaran masih sulit dianggap sebagai bagian dari kekerasan. Padahal hal tersebut ada di dalam,

"hal-hal sederhana seperti privasi, misalnya,....pengecekan secara diamdiam atas telepon atau surat elektronik pacar, atau peretasan akun Facebook. Cemburu ekstrim, posesif dan rasa tidak aman dianggap sebagai ekspresi cinta. Merendahkan pacar atau mempermalukannya di depan umum....demikian juga mengisolasi pasangan dari keluarga atau teman-temannya (Asmarani, 2015)."

Kekerasan yang terjadi dalam relasi pacaran sangat terkait dengan gender. Perempuan melakukan kekerasan untuk membela diri sedangkan laki-laki menggunakan kekerasan untuk menanamkan kontrol. Baik laki-laki maupun perempuan bisa menjadi korban ataupun pelaku (Yayasan Pulih, 2018). Namun, perempuan lebih rentan mendapatkan kekerasan seksual (Khaninah \&Widjarnako, 2015). Bentuk-bentuk kekerasan juga sangat banyak. Setidaknya adalah 5 bentuk KDP yakni: (a) Kekerasan Psikis; (b) Kekerasan Verbal; (c) Kekerasan Seksual; (d) Kekerasan Digital; (e) Kekerasan Finansial

Sayangnya, dibandingkan dengan kasus kekerasan yang lain, kasus KDP masih kurang menjadi perhatian. KDP masih dianggap terlalu abstrak karena relasi 
Kisah Cinta Tidak Indah : Studi Kekerasan dalam Relasi Pacaran Mahasiswa di Fakultas Ilmu Sosial dan Ilmu Politik Universitas Cenderawasih Jayapura

yang menaunginya tidak berbadan hukum sehingga pihak korban sulit melaporkan atau menuntut keadilan; bahkan dari perspektif hukum sendiri, agak sulit menjaring pelaku KDP ke dalam ranah hukum karena ambiguitas bahasa hukum dalam melihat KDP serta aparat hukum yang masih timpang dalam melihat relasi laki-laki dan perempuan dalam pacaran. Oleh sebab itu menarik untuk mendapatkan gambaran lebih lanjut sekaligus utuh mengenai fenomena KDP dalam relasi pacaran, dengan mencari tahu bagaimana KDP terjadi dalam relasi pacaran berdasarkan pengalaman pelaku maupun pengalaman korban.

\section{Metode Penelitian}

Penelitian ini dilaksanakan di Fakultas Ilmu Sosial dan Ilmu Politik Universitas Cenderawasih (Uncen) Jayapura Papua, khususnya di Program Studi Kesejahteraan Sosial. Dengan pertimbangan bahwa fakultas ini adalah salah satu fakultas dengan kasus KDP yang cukup banyak muncul di permukaan. Pemilihan lokasi penelitian ini juga bukan pula hendak menegasikan kasus KDP di program studi dan fakultas lain di lingkungan Uncen, maupun di universitas lain. Pemilihan lokasi penelitian ini dilakukan dengan pemahaman sederhana: kekerasan dalam pacaran terjadi di sekitar kita.

Penelitian dilakukan selama 4 bulan sejak Mei 2019-September 2019 dengan pendekatan fenomenologi. Pendekatan ini dipilih untuk mengeksplorasi pengalaman pelaku dan korban lebih dalam sehingga dapat mengungkap KDP. Fenomenologi juga membantu melihat pengalaman dari perspektif korban dan perspektif pelaku tanpa menghakimi dan menyalahkan. Penelitian juga tidak dilakukan secara terjadwal karena sangat bergantung dari kesiapan para informan untuk bercerita. Tempat penelitian juga ditentukan oleh informan; tergantung pada kenyamanan informan untuk bercerita dengan leluasa.

Teknik penentuan informan dilakukan dengan teknik Bola Salju (Snow Ball). Proses penentuan dan menemukan informan ini juga tidak mudah karena tidak banyak mahasiswa yang berani dan bersedia menceritakan pengalaman kekerasan mereka dalam pacaran. Beberapa kali informan yang sudah sepakat bercerita, tiba-tiba membatalkan janji satu jam sebelum pertemuan bahkan berubah 
pikiran menjadi informan. Kejadian ini menunjukan bahwa pengalaman kekerasan bukanlah pengalaman yang menyenangkan apalagi untuk diceritakan kepada khalayak umum. Jika berpikir dari perspektif informan, jangan-jangan membayangkan bahwa pengalaman kelamnya bisa dibaca oleh banyak orang juga menjadi teror yang menakutkan tersendiri.

Oleh sebab itu, identitas empat informan penelitian ini dirahasiakan. Segala petunjuk yang mengarahkan pada identitas asli informan diganti. Empat informan penelitian ini terdiri dari dua laki-laki dan dua perempuan. Dua dari informan ini berada dalam relasi pacaran, sehingga otomatis akan didapatkan pengalaman dari perspektif pelaku dan korban dalam relasi pacaran yang utuh. Kemudian dua informan lainnya berada dalam relasi pacaran yang berbeda. Satu informan menceritakan pengalaman dari perspektif korban dan satu lagi informan menceritakan pengalaman dari perspektif pelaku.

Teknik pengambilan data adalah wawancara mendalam dengan pertanyaan semi terstruktur, dimana identitas informan dijamin kerahasiaannya. Wawancara bergulir dengan pertanyaan yang mengalir dan direkam. Dokumentasi tidak dilakukan demi menjaga kerahasiaan identitas informan.

\section{Hasil dan Pembahasan}

Kekerasan dalam pacaran mudah ditemukan dalam pengalaman sehari-hari. Namun meski termasuk sering bisa ditemukan, fenomena ini jarang dibahas terbuka. Oleh sebab itu melalui bantuan dari Taro, Jolly, Fressy, dan Sanadril, pengalaman kekerasan dalam pacaran baik dari perspektif pelaku dan perspektif korban akan diuraikan dalam bagian-bagian berikut.

\section{KDP dalam Perspektif Pelaku}

\section{Pengalaman Taro}

Taro memiliki pacar bernama Tingki. Mereka sudah bersama sekitar 2 tahun. Namun Taro mengakui bahwa ia belum memiliki perasaan terhadap Tingki. Memang pada awalnya, Taro yang mendekati Tingki dan Tingki juga merespon. Seiring berjalan waktu Tingki makin baik dan makin mendekat dengan Taro. Bahkan Tingki rela membawakan bekal tiap hari untuk Taro. Sikap Tingki yang 
Kisah Cinta Tidak Indah : Studi Kekerasan dalam Relasi Pacaran Mahasiswa di Fakultas Ilmu Sosial dan Ilmu Politik Universitas Cenderawasih Jayapura

baik ini kemudian membuat Taro memilih menjalankan relasi mereka meski belum ada perasaan spesial.

Taro sendiri bingung jika mendefinisikan hubungannya dan Tingki sebagai hubungan berpacaran. Taro bahkan menandakan kapan ia dan Tingki resmi berada dalam hubungan pacaran adalah saat mereka pertama kali melakukan hubungan seksual. Hubungan seksual itu pun dilakukan atas dasar butuh dan bukan atas dasar sayang.

Ketiadaan rasa sayang dan cinta dalam hubungan Taro dan Tingki menjustifikasi Taro untuk memiliki hubungan dengan beberapa perempuan lain sekaligus. Hubungan Taro yang banyak ini membuat Tingki sedih dan sakit hati. Tingki sering bertanya dan menangis meminta penjelasan dari Taro karena ia banyak mendengar rumor tentang Taro yang berselingkuh. Namun semua pertanyaan-pertanyaan Tingki ditepis Taro dengan rayuan dan kebohongankebohongan kecil. Tingki yang tadinya sedih bisa menjadi tenang kembali.

Ketiadaan rasa cinta itu juga tetap membuat Taro melanjutkan hubunganhubungannya dengan perempuan yang berbeda-beda, bahkan saat Tingki harus hamil. Tanpa Tingki dan Taro pernah sepakati, Tingki hamil. Taro mengakui bahwa kehamilan tersebut adalah kelalaiannya. Ia mengatakan ia lalai namun ia juga tidak bisa menahan untuk tidak pakai pengaman atau mengeluarkan sperma di luar vagina Tingki. “..Barang dunia mo”, begitu istilah Taro (Wawancara, Juli 2019). Taro juga mengatakan perasaannya biasa saja terhadap Tingki sewaktu tahu Tingki hamil. Dengan yakin Taro mengatakan bahwa ia, “...tidak peduli saja, saya tidak peduli (Wawancara, Juli 2019)".

Namun selama proses kehamilan Tingki, Taro berusaha bertanggung jawab dengan memberitahukan orang tuanya. Taro juga membawa orang tuanya untuk menemui orang tua Tingki. Setelah ada pembicaraan antar keluarga, Tingki akhirnya tinggal di rumah orang tuanya dan kemudian mengambil cuti. Pada saat ini Taro dan Tingki dalam keadaan terpisah.

Taro mengakui di awal hubungannya ia pernah memutuskan Tingki karena merasa bosan. Namun, ia membatalkan niat itu saat Tingki “...bajalan kaki dari de punya kos sampai ke sa punya kos sambil menangis di depan sa begitu.....kayak 
mengemis cinta saja" (Wawancara, Juli 2019). Atas dasar kasihan dan iba, Taro tetap menjalankan relasi mereka. Namun seiring berjalan waktu, Taro pun tidak bisa merelakan tingki, meski rasa sayang itu masih tidak ada. Menurut Taro, Tingki adalah perempuan yang baik. Tingki selalu peduli dengan Taro dan mengurus Taro seperti memasak untuknya, mencuci semua pakaian-pakaian kotornya, membelikannya rokok dan pulsa bahkan Tingki selalu menjadi orang yang menyelamatkannya di akhir bulan saat Taro sudah kehabisan uang bulanan.

Salah satu alasan kuat yang menurut Taro menjadi pemicu ia tidak punya rasa dengan Tingki adalah menurutnya Tingki itu kurang cantik dibanding dengan selingkuhan-selingkuhannya. Taro mengatakan kekurangcantikan Tingki ini kadang membuatnya malu untuk jalan di depan umum, “...macam bagaimana eh, ihh harga diri jatuh skali" (Wawancara Juli 2019). Jika Taro berjalan bersama Tingki di depan umum, Taro menjaga jarak serta menolak bergandengan tangan. Kalaupun mereka bisa berjalan bergandengan tangan, itu pun karena Tingki memaksanya dan mencakar-cakar tangannya. Tapi Taro tidak pernah tahan berlama-lama bergandengan di depan umum dengan Tingki. Taro juga bahkan menolak berteman dengan Tingki. Akun Facebook Tingki diblokir oleh Taro agar Tingki tidak bisa menandainya dan mengungkapkan hubungan mereka di beranda Facebook.

Taro menyadari bahwa apa yang ia lakukan pada Tingki itu salah. Ia mengatakan bahwa Tingki sering menangis karena kelakuannya. Taro bahkan punya ketakutan tersendiri kalau di masa depan saat ia sudah menyayangi Tingki, Tingki malah akan melakukan hal sama padanya. Namun walaupun pemikiran tersebut sering melintas, Taro masih enggan untuk mengakhiri hubungannya dengan selingkuhan-selingkuhannya.

Bagi Taro keberadaan selingkuhan-selingkuhannya ini sangat menghibur hatinya. Walaupun Taro tidak melakukan hubungan seksual dengan mereka, namun Taro juga memanfaatkan kecantikan mereka untuk berjalan di depan umum, menghabiskan uang mereka untuk rokok dan jalan-jalan serta bersenang-senang. “...Biasanya kalau ketemu di kos, sa pegang tangan, peluk dan bahkan sa cium, setelah itu sa suruh pulang (Wawancara, Juli 2019)". Menurut Taro hal seperti itu wajar ia lakukan karena ia memang tidak punya hati dengan selingkuhan- 
Kisah Cinta Tidak Indah : Studi Kekerasan dalam Relasi Pacaran Mahasiswa di Fakultas Ilmu Sosial dan Ilmu Politik Universitas Cenderawasih Jayapura

selingkuhannya. Taro mengatakan bahwa saat dia punya hati pada perempuan baru ia bisa berkorban.

Sedangkan untuk anak Taro, saat ini Taro belum pernah bertemu dengannya. Taro mengatakan pada malam sebelum Tingki melahirkan, orang tua Taro sudah menyuruh Taro untuk datang ke kampung untuk menjenguk Tingki dan anaknya. Namun Taro sengaja membuat dirinya ketinggalan peswat sehingga ia tidak jadi ke kampung. Hingga sekarang Taro masih belum memiliki keinginan kuat untuk menjenguk Tingki dan anaknya di kampung. Ia mengatakan selama anaknya di tempat yang aman, dia tidak perlu terlalu khawatir.

Saat ini hubungan Taro dan Tingki agar merenggang. Mereka jarang komunikasi. Namun Taro sempat berpikir bahwa mungkin seiring berjalan waktu ia bisa menerima Tingki dengan seutuhnya dan apa adanya. Tapi ada juga bagian dari sisi Taro untuk tidak terlalu peduli.

\section{Pengalaman Sanadril}

Sanadril memiliki relasi pacaran dengan Jolly. Usia relasi mereka adalah dua tahun. Sanadril menyukai Jolly dikarenakan Jolly adalah perempuan yang “...disiplin dan juga dalam urusan perkuliahan orangnya rajin dan tertib. Orangnya juga punya pendirian” (Wawancara. Agustus 2019). Sanadril memiliki perasaan yang mendalam kepada Jolly. Ia mengganggap hubungannya dengan Jolly adalah hubungan yang serius. Bahkan Sanadril mengatakan bahwa ia sudah menganggap Jolly sebagai istrinya sendiri. Komitmen Sanadril pada Jolly bisa terlihat dari Sanadril yang terbuka mulai dari memberikan kata kunci akun Facebook hingga terbuka secara finansial kepada Jolly. Sanadril jika mendapatkan uang dari kerjaannya akan segera memberikannya kepada Jolly.

Dikarenakan keseriusan Sanadril tersebut, Sanadril juga menginginkan Jolly untuk dengar-dengaran kepadanya. Sanadril ingin Jolly mengikuti standarnya mulai dari hal berbicara, cara duduk, hingga cara berpakaian. Seperti yang diceritakan oleh Sanadril:

“...Tetapi macam sesuatu yang saya kurang suka tetapi dia menghiraukan, begitu kadang bikin saya jadi marah. Seperti, cara duduknya yang tidak sopan, dan 
cara berpakaian kalau di tempat umum. Hal-hal itulah yang memicu kemarahan saya" (Wawancara, Agustus 2019)

Namun menurut Sanadril, Jolly sangat sulit diberitahu. Jolly sering tidak mendengarkannya. Hal yang paling sering Jolly lalaikan adalah masalah berpakaian. Sanadril melihat bahwa Jolly sering berpakaian terbuka di kos padahal kosan Jolly adalah kosan bebas dimana banyak laki-laki keluar masuk dan mondar-mandir di dalam kosan itu.

"Seperti gaya berpakaian yang seksi-seksi kalau kita di kos-kosan. Dikarenakan di kos itu kos bebas, itu bukan hanya kita berdua yang tinggal, tetapi ada orang lain juga yang tinggal. Jadi maunya saya cara berpakaian dia harus sopan, walaupun di dalam kos. Dan aurat perempuan itu harus dijaga" (Wawancara, Agustus 2019)

Mulai dari sinilah, relasi pacaran Sanadril dan Jolly membudayakan kekerasan. Sanadril yang bertubuh besar tidak segan-segan untuk memukul Jolly yang bertubuh kecil jika Sanadril melihat Jolly berpakaian terbuka. “...Biasanya saya menegur, tetapi dia keras kepala, di situ kadang saya marah sehingga memukul dan bahkan menamparnya" (Wawancara, Agustus 2019).

Kebiasaan memukul Jolly akhirnya berkembang, tidak hanya melulu soal masalah pakaian. Sanadril sering memukul Jolly untuk alasan sepele. Sanadril bahkan juga tidak peduli jika harus membentak, memarahi atau memukul Jolly di depan umum. Seperti yang dikatakan Sanadril,

“...Kadang di jalan raya selesai makan di warung, jikalau dia melakukan sedikit kesalahan di situ saya akan marah, membentak dan bahkan memukul dia di tempat umum" (Wawancara, Agustus 2019)

Kebiasaan bertengkar Sanadril dan Jolly yang hebat dan besar bahkan sampai pernah dibawakan ke pihak kepolisian. Namun meski begitu, Sanadril tidak juga menghentikan kebiasaannya untuk memukul atau memarahi Jolly. Sanadril bahkan juga memukul Jolly tidak hanya dalam keadaan sadar, tetapi juga saat Sanadril berada dalam pengaruh minuman keras. Sanadril adalah peminum aktif. Ia sering sekali pulang ke kos dalam keadaan mabuk. Sanadril dan Jolly yang sudah tinggal satu kos ini, sering berpindah-pindah kos karena kebiasaan Sanadril saat 
Kisah Cinta Tidak Indah : Studi Kekerasan dalam Relasi Pacaran Mahasiswa di Fakultas Ilmu Sosial dan Ilmu Politik Universitas Cenderawasih Jayapura

mabuk yang suka membuat keributan. Kemudian saat Sanadril pulang ke kos dalam keadaan mabuk tengah malam, Sanadril suka menginginkan untuk berhubungan seks. Jolly yang biasanya sudah tidur jika menolak permintaan Sanadril ini akan langsung memukul atau memaki Jolly.

Sanadril memang adalah orang yang keras. Ia sejak kecil tidak hidup bersama orang tuanya. Ia hidup dan dibesarkan oleh kakak dan omnya. Kehidupan yang jauh dari orang tua ini membentuk karakter Sanadril menjadi keras. Sanadril menyukai segala sesuatu sebisa mungkin berada dalam kontrolnya, termasuk keberadaan Jolly. Sanadril menginginkan Jolly untuk dengar-dengaran kepadanya dan menuruti kemauannya.

Sanadril juga tidak menyukai karakter Jolly yang pencemburu. Menurut Sanadril kecemburuan sangat tidak penting bagi hubungan mereka. Sanadril mengatakan bahwa Jolly terkadang seperti menuduh dan menginterogasi dia. Padahal Sanadril merasa sudah jujur dan tidak melakukan hal yang macam-macam pada Jolly. Bahkan Sanadril mengatakan bahwa baik Sanadril dan Jolly saling mengetahui kata sandi masing-masing akun media sosial. Menurut Sanadril itu sudah menunjukkan keterbukaannya.

Sanadril juga tidak memiliki rasa bersalah ataupun iba terhadap Jolly setelah memukul Jolly. Menurut Sanadril, hal yang ia lakukan bertujuan,

"Biar dianya (Jolly) tobat, memang saya orangnya selagi masih marah tidak bisa mengampuni orang . Jadi, bagaimana ee, kalau (saya) marah dia, itu sulit skali baru dengar. Jadi mendingan saya pukul sampai saya puas barulah saya lepas" (Wawancara, Agustus 2019).

\section{KDP dalam Perspektif Korban}

\section{Pengalaman Jolly}

Jolly berada dalam relasi pacaran dengan Sanadril. Pada awalnya Jolly memang yang lebih dulu menaruh perasaan pada Sanadril. Menurut Jolly hal yang membuat Sanadril menarik adalah Sanadril ini memiliki karakter yang sangat maskulin, 
“...maksudnya dia laki-laki skali begitu. Biasanyakan kalau dilihat-lihat laki-laki ada yang biasa suka gabung dengan perempuan-perempuan. Tetapi dia orangnya tidak, hal itu yang membuat saya suka" (Wawancara, Agustus 2019)

Hubungan mereka awalnya menyenangkan. Namun, bibit-bibit kekerasan muncul karena ada masalah kecemburuan. Jolly mengakui, ia adalah orang yang pencemburu. Ia suka menanyakan hal detil tentang perempuan tertentu kepada Sanadril. Kecemburuan Jolly muncul karena,

“... mungkin sudah mulai lihat kita berdua sama-sama serius, sehingga rasa sayang itu semakin kuat, sehingga rasa cemburu pun juga semakin kuat. Padahal tidak seharusnya cemburu." (Wawancara, Agustus 2019)

Kekerasan lain juga muncul dari Sanadril karena masalah berpakaian Jolly. Sanadril tidak menyukai jika Jolly memakai pakaian terbuka.

"Iya..saya tau, saya salah sering saya berpakaian yang seksi. Pada dasarnya kos- $\quad$ kosan yang kami tinggali adalah kos-kosan umum yang begitu banyak orang, ada wanita bahkan ada juga laki-laki. Sering kali saya mendengarkan terguran dia dan bahkan saya menerimannya" (Wawancara, Agustus 2019)

Pada awal Sanadril memukul Jolly, Jolly sangat tidak terima dengan perilaku tersebut. Namun Jolly juga tidak berdaya untuk membalas, seperti yang dikatakan oleh Jolly,

“....kalau saya orangnya tidak suka kalau dibentak atau dipukul oleh orang, biasanya kalau saya dibentak atau dipukul pasti saya akan balas. Tetapi kalau saya dimarahin atau dibentak oleh dia (Sanadril), saya tidak bisa untuk membalasnya" (Wawancara, Agustus 2019)

Saat Sanadril memukul Jolly, Jolly hanya bisa menangis dan marah dalam diam. Kemarahan Jolly hanya ditunjukkan dengan sikap diam dan cuek pada Sanadril. Sikap diam dan cuek ini juga bahkan sering memancing Sanadril untuk tambah marah dan tambah memukul Jolly. Bahkan ketika Sanadril sudah memukul Jolly apalagi dalam keadaan mabuk, Sanadril sulit dihentikan. Butuh orang lain untuk menghentikan Sanadril. Jolly bercerita bahwa saat ia dipukul, biasanya dia, 
Kisah Cinta Tidak Indah : Studi Kekerasan dalam Relasi Pacaran Mahasiswa di Fakultas Ilmu Sosial dan Ilmu Politik Universitas Cenderawasih Jayapura

“...meminta maaf sambil menangis-nangis. Tetapi Sanadril tidak menghiraukan. Sehingga pemilik kos atau penjaga kos mengambil tindakan, dengan menghubungi polisi dikarenakan tidak ada orang yang bisa mengatasi atau menyuruh kita untuk berhenti bertengkar.Polisi datang sambil menasehati kami berdua" (Wawancara Agustus 2019).

Sanadril adalah peminum aktif dan memiliki kebiasaan membuat keributan pada saat mabuk. Menurut Jolly, ia dan Sanadril sudah berpindah-pindah kosan sebanyak tiga kali dikarenakan Sanadril mabuk berat dan membuat keributan di kos. Hal ini sangat mengganggu penghuni dan pemilik kos sehingga pemilik kos memanggil polisi. Saking seringnya berurusan dengan polisi, pada kasus yang ke empat kali, Sanadril ditahan di sel selama satu malam. Pada saat Sanadril mabuk berat, Sanadril juga pernah memaksa Jolly untuk berhubungan seksual. Jika Jolly tidak mengantuk, maka Jolly bersedia berhubungan seks. Jika Jolly menolak bangun, Sanadril akan marah dan mereka akan bertengkar.

Jolly sendiri berkata bahwa ia sakit hati dengan perlakuan Sanadril. Efek dari pemukulan itu juga membuat Jolly sering ketakutan, terutama saat Sanadril bergerak mengangkat tangannya. Jolly mengatakan, saat Sanadril mengangkat tangan, entah untuk mengambil sesuatu, Jolly langsung mengira bahwa Sanadril akan memukulnya. Jolly biasanya reflek akan menutup wajahnya dengan tangan untuk melindungi diri.

Tapi Jolly berharap ke depannya Sanadril bisa berubah. Menurut Jolly, Sanadril sebenarnya adalah laki-laki yang baik. Sanadril bisa menerima semua kekurangan dan masa lalu Jolly. Sanadril juga adalah tipikal laki-laki yang royal dan tidak pelit. Jika Sanadril mulai memukulnya karena alasan pakaian yang terbuka atau karena alasan sepele, Jolly sering sekali menyalahkan dirinya sendiri. Jolly mengatakan bahwa kelalaiannyalah yang membuat Sanadril marah.

Jolly sebenarnya sudah berusaha untuk mendengarkan dan mengikuti katakata Sanadril. Namun, entah mengapa Jolly juga sering sekali lupa untuk melaksanakan janjinya pada Sanadril. Hal inilah yang membuat Sanadril marah dan memukulnya. Jolly mengakui bahwa setelah dipukul, Sanadril memang tidak secara langsung meminta maaf. Sanadril jika sudah tidak marah akan bersikap seperti 
biasa. Sedangkan bagi Jolly setelah pertengkaran, ia sebenarnya membutuhkan waktu untuk diam dan sendiri. Namun, Sanadril mengharapkannya untuk juga bersikap biasa dan tidak marah. Biasanya kejadian ini akan memicu pertengkaran baru lagi.

Jolly sebenarnya sangat berharap Sanadril untuk sedikit mengerti dia. Jolly membutuhkan lebih banyak waktu untuk pulih setelah pertengkaran apalagi setelah Sanadril memukulnya. Jika memungkinkan, setelah pertengkaran biasanya Jolly akan pergi pulang ke rumah orang tuanya untuk menenangkan diri. Setelah emosinya reda, baru kemudian Jolly akan kembali datang kepada Sanadril dan bersikap seperti biasa.

Jolly berasal dari keluarga terpelajar. Ayah Jolly adalah seorang guru. Jolly sendiri juga berkarakter lemah lembut, pendiam, dan sopan. Namun hubungannya dengan Sanadril tidak diketahui keluarganya, karena Jolly belum diijinkan pacaran oleh orang tuanya. Jadi masalahnya dengan Sanadril tidak Jolly ceritakan pada keluarganya. Jolly hanya bercerita pada teman baiknya saja. Itupun Jolly tidak terlalu terbuka. Jolly merasa lebih baik dia menyimpan cerita itu sendiri.

\section{Pengalaman Fressy}

Fressy berada dalam relasi pacaran yang oleh masyarakat Fressy dianggap sudah menikah. Fressy memiliki pasangan bernama Gune. Fressy dan Gune berada dalam relasi sudah sekitar empat tahun. Awal mula bertemu, Fressy dan Gune mengalami masa pendekatan yang cepat, itupun hanya lewat SMS dan telepon. Dalam kesan pertama Fressy, Gune adalah laki-laki yang baik karena Gune tidak minum dan tidak merokok. Kemudian dalam masa pendekatan tersebut, Gune langsung menyatakan niatnya untuk hidup bersama dengan Fressy. Dalam adat Sentani, pilihan hidup bersama seperti suami isteri bisa dilakukan selama ada kesepakatan dari keluarga pihak laki-laki dan pihak perempuan walaupun tidak ada ikatan pernikahan atas dasar agama dan negara.

Niat Gune juga disambut baik Fressy. Dengan status mahasiswa yang masih semester awal, Fressy mengambil keputusan untuk hidup bersama dengan Gune. Akhirnya orang tua Gune mendatangi orang tua Fressy dan membuat kesepakatan sehingga Fressy bisa hidup bersama dengan Gune di rumah orang tua Gune. 
Kisah Cinta Tidak Indah : Studi Kekerasan dalam Relasi Pacaran Mahasiswa di Fakultas Ilmu Sosial dan Ilmu Politik Universitas Cenderawasih Jayapura

Ketika sudah hidup bersama, Fressy mulai mendapati bahwa Gune ternyata pemarah, sensitif dan sangat kasar. Fressy sering dipukuli oleh Gune untuk masalah-masalah yang sepele. Sumber pertengkaran mereka di awal adalah saat Fressy menolak berhubungan seks dengan Gune. Fressy bercerita bahwa tingkat keinginan seksual Gune sangat tinggi. Dalam sehari Gune bisa meminta berhubungan seks berkali-kali dan itu ingin dilakukan Gune setiap hari. Seperti yang diceritakan Fressy bahwa,

“...iya dia (Gune) maunya begitu (seks setiap hari). Tapi saya tidak mau. Saya punya badan sakit-sakit. De (Gune) marah kalau sa tidak kasih (seks). De suka pukul, de marah." (Wawancara, September 2019).

Fressy yang tidak setiap hari menginginkan berhubungan seksual menolak Gune. Gune yang tidak terima akhirnya memukul Fressy dan mengeluarkan kata-kata kotor pada Fressy seperti lonte atau mengeluarkan kalimat-kalimat seperti, "iyo ko pergi sudah kasih ko pu tubuh sama laki-laki lain" (Wawancara, September 2019). Kata-kata itu sangat menyakitkan Fressy, tapi Fressy tetap saja diam dan tidak bisa membalas.

Penyebab lain yang menjadi sumber kemarahan Gune adalah kecemburuan dan kecurigaan yang sangat tinggi pada Fressy. Gune sangat tidak menyukai jika Fressy bergaya dan memoles wajahnya. Jika Gune melihat Fressy memakai lipstik atau memakai baju yang ketat dan membentuk lekuk tubuh, Gune tidak segan-segan untuk memukul Fressy bahkan menyeret Gune di depan banyak orang.

Fressy juga tidak bisa pulang terlambat. Suatu ketika Fressy mengikuti kegiatan yang menyebabkan ia pulang malam. Gune kesal karena lama menunggu Fressy pulang. Gune sudah berpikiran negatif terhadap Fressy,

“...de (Gune) sangkanya saya ada pergi dengan laki-laki ke Kantor X. Pas pulangnya itu sudah, langsung de pukul saya di atas motor. Saya jatuh, de tambah injak-injak ke bawah lagi. Pas itu di jalan masuk depan rumah" (Wawancara, September 2019).

Kekerasan yang diterima Fressy memang sudah masuk pada tahap yang brutal. Karena Gune tidak hanya memukul, melainkan juga menendang dan menginjak Fressy. Gune juga tidak segan-segan menggunakan benda-benda di 
sekitarnya untuk melampiaskan kemarahannya pada Fressy. Fressy bercerita bahwa punggungnya pernah dipukul dengan kayu balok hingga punggungnya memarmemar kebiruan. Fressy juga pernah dilempar dengan batu dan mengenai matanya sehingga matanya cedera. Gune tidak segan-segan memukul dan menghajar Fressy. Menurut Fressy, kecemburuan Gune yang tidak wajar pada Fressy ini disebabkan karena Gune tidak mengetahui lingkungan pergaulan mahasiswa. Fressy dan Gune mengalami kesenjangan pendidikan yang cukup tinggi. Fressy adalah mahasiswa sedangkan Gune tidak tamat Sekolah Dasar. Alasan Gune tidak bersekolah dikarenakan tangan Gune berbeda dari tangan biasanya. Tangan Gune berbeda ukuran dengan tangannya yang lain. Pada masa sekolah, Gune selalu dihina oleh teman-temannya. Hal ini yang membuat Gune tidak ingin melanjutkan pendidikannya. Perbedaan tingkat pendidikan ini membuat Gune tidak tahu lingkungan dan dunia mahasiswa sehingga Gune selalu cemburu dan curiga pada Fressy jika pergi bersama teman-temannya.

Selain dipukul, Fressy pun pernah diselingkuhi oleh Gune. Fressy pernah secara tidak sengaja melihat SMS Gune dengan perempuan lain. Gune pun terangterangan mengakui melakukan perselingkuhan karena salah Fressy yang tidak pernah mau mendengar Gune dan selalu menolak berhubungan seks dengan Gune. Fressy juga tidak pernah diberikan uang oleh Gune. Uang kuliah dan uang hidup Fressy masih ditanggung orang tua Fressy.

Kekerasan yang dilakukan Gune pada Fressy diketahui oleh mama mantu dan bapa mantu Fressy. Namun, keluarga Gune tidak bereaksi dan membiarkan saja. Fressy bercerita bahwa ayah Gune juga sering memukuli ibu Gune. Kejadian seperti itu sudah lumrah dalam keluarga Gune. Sedangkan Fressy berasal dari keluarga yang sangat harmonis dengan ayah ibu yang saling akur dan sama sekali tidak pernah bertengkar di depan Fressy dan adik-adiknya.

Sikap kasar Gune pada Fressy membuat orang tua Fressy tidak tinggal diam. Fressy pernah disuruh orang tuanya untuk meninggalkan Gune. Fressy pernah menuruti orang tuanya, namun tidak selang berapa lama, Gune dan keluarganya datang ke rumah orang tua Fressy untuk menjemput Fressy. Kejadian ini membuat Fressy dan orang tuanya luluh sehingga akhirnya membiarkan Fressy kembali ke 
Kisah Cinta Tidak Indah : Studi Kekerasan dalam Relasi Pacaran Mahasiswa di Fakultas Ilmu Sosial dan Ilmu Politik Universitas Cenderawasih Jayapura

rumah Gune. Kejadian ini tidak berlangsung satu kali saja. Kejadian ini sudah berlangsung beberapa kali, yakni Fressy lari dari rumah Gune ke rumah orang tuanya. Lalu tidak lama kemudian Gune dan keluarganya datang ke rumah orang tua Fressy untuk menjemput Fressy dan Fressy akhirnya kembali pada Gune.

Fressy mengatakan bahwa alasan ia kembali pada Gune adalah karena ia mengasihi Fressy. Selain itu keberadaan anak di antara mereka membuat Fressy ingin bertahan. Anak yang dilahirkan oleh Fressy ditahan oleh Gune dan keluarganya; anak Fressy dijauhkan darinya oleh Gune dan keluarganya. Oleh sebab itu, meski sudah berusaha lari dari relasi ini berkali-kali, namun Fressy juga telah berkali-kali kembali karena mengingat anaknya.

\section{Ada Kekerasan dalam Relasi Pacaran: Akar dan Manifestasi Kekerasan dalam Pacaran}

Berdasarkan pengalaman keempat informan tersebut diketahui bahwa KDP terjadi karena didukung oleh pihak korban maupun pihak pelaku. Pihak korban merasa tidak berdaya untuk melawan dan terkadang menyalahkan dirinya atas kekerasan tersebut sedangkan pihak pelaku juga membenarkan dirinya atas tindakan-tindakan kekerasan yang mereka lakukan. Artinya ada struktur timpang yang membuat relasi pacaran para informan tidak setara, yakni laki-laki sebagai pihak dominan dan perempuan sebagai pihak subordinat.

Dari perspektif pelaku, untuk pengalaman Sanadril, keberadaan rasa cinta dan sayang dalam hubungan yang menjadi pembenaran bagi Sanadril untuk melakukan kekerasan pada Jolly. Pengalaman Sanadril ini mengamini konsep cinta sebagai justifikasi untuk melakukan kekerasan dalam pacaran,; bahwa cinta adalah kepemilikan atau kontrol. Pengalaman Sanadril juga sama seperti pengalaman Fressy yang mendapat kekerasan dari Gune. Gune yang merasa sudah memiliki Fressy merasa berhak untuk memperlakukan Fressy sesuka hatinya. Sedangkan untuk pengalaman Taro, justru ketiadaan cintalah yang membuat ia tidak merasa bersalah atau legal saja untuk melakukan perselingkuhan dan bersikap cuek terhadap Tingki. Namun dari perspektif Tingki, rasa sayangnya pada Taro yang membuatnya rela menjalani hubungan menyakitkan dengan Taro. 
Kemudian sikap Jolly dan sikap Fressy yang diam dan tidak melawan menjadi dasar bagi pembenaran setiap perilaku kekerasan yang mereka terima dari pasangan mereka. Bahkan dalam kasus Jolly, ada upaya menyalahkan diri sendiri yang cukup besar saat Sanadril melakukan kekerasan padanya. Jolly merasa bahwa kemarahan dan sikap emosional Sanadril dikatalisatori oleh sikap keras kepalanya. Sedangkan untuk kasus Fressy, keberadaan anak dari hubungannya dengan Gune yang membuat dia rela kembali pada Gune dan menerima segala konsekuensinya. Selain rasa sayang yang besar pada pasangan yang masih mendominasi alasan kuat dari Fressy dan Jolly untuk bertahan dalam relasi tersebut.

Kekerasan dalam pacaran juga dilanggengkan oleh budaya dimana pelaku dan korban berada. Hal ini sangat terihat dari relasi Fressy dan Gune. Gune tidak merasa bersalah memukul bahkan brutal terhadap Fressy, karena Ayah Gune juga sering memukul Ibu Gune. Orang tua Gune, meski tahu apa yang terjadi pada Fressy, tidak bisa menghentikan Gune ketika ia sedang memukul Fressy. Hal ini sangat mencerminkan bahwa kekerasan lumrah di dalam relasi cinta laki-laki dan perempuan dewasa, setidaknya di budaya keluarga tempat Gune dibesarkan.

Kemudian dari uraian pengalaman para informan didapati bahwa bentuk kekerasan yang sering terjadi adalah:

\section{Kekerasan Psikis/ Emosional}

Bentuk kekerasan ini terlihat menonjol dalam pengalaman Taro. Taro meskipun tidak pernah memukul atau memaki pasangannya, tetapi Taro melakukan kekerasan emosional dengan tidak menghargai pasangannya sebagaimana mestinya, sering berbohong pada pasangannya serta memiliki hubungan dengan perempuan lain. Kekerasan psikis ini pasti membuat pasangan Taro berada dalam lingkaran kesedihan dan ketakutan yang panjang. Selain itu Taro juga tidak menghargai pasangannya sebagaimana mestinya dan membandingkan pasangannya dengan perempuan lain. Taro juga tidak peduli bahkan saat pasangan Taro melahirkan anak mereka. Ketidakpedulian juga merupakan aspek yang sangat bersifat toxic dalam relasi pacaran serta sangat berefek buruk pada emosi. 
Kisah Cinta Tidak Indah : Studi Kekerasan dalam Relasi Pacaran Mahasiswa di Fakultas Ilmu Sosial dan Ilmu Politik Universitas Cenderawasih Jayapura

Kekerasan psikis juga muncul dalam pengalaman Jolly dan Sanadril dimana Jolly selalu merasa bersalah dan merasa khawatir jika ia melakukan kesalahan dan tidak mengikuti apa yang diinginkan Sanadril. Perasaan khawatir ini adalah efek dari kekerasan emosional yang dilakukan oleh Sanadril, yakni tidak membiarkan Jolly menjadi dirinya sendiri serta membatasi pergerakan Jolly. Jolly juga mengalami trauma yang cukup serius, karena Jolly selalu merasa Sanadril akan memukulnya setiap kali Sanadril mengangkat tangan.

Pola yang sama juga muncul dari pengalaman Fressy dimana ia dibatasi dan dikontrol mulai dari apa yang dipakai hingga pelarangan menggunakan kosmetik, sehingga ia tidak berani mengekplorasi kosemetik dan fashion apalagi di depan Gune. Fressy juga menjadi pribadi yang tertutup dan jarang bergaul.

\section{Kekerasan Fisik dan Verbal}

Bentuk kekerasan ini paling sering terjadi dan terlihat jelas dalam relasi pecaran keempat informan terutama di pengalaman Sanadril dan Jolly serta pengalaman Fressy. Pemukulan, pembentakan, dan penggunaan bahasa-bahasa yang tidak pantas dilakukan oleh pelaku dan diterima oleh korban sebagai bentuk pelampiasan kemarahan yang pada awalnya tidak diterima namun seiring berjalannya waktu menjadi terbiasa dengan sikap-sikap tersebut. Contoh kekerasan tersebut seperti pengalaman Fressy yang disebut lonte oleh Gune atau Jolly yang sedikit demi sedikit mulai menerima jika Sanadril membentaknya di depan umum karena ia memakai baju yang tidak pantas di mata Sanadril.

\section{Kekerasan Finansial}

Kekerasan finansial ini terlihat dari pengalaman Taro yang memanfaatkan kebaikan dan kepandaian pacarnya dalam mengatur keuangan untuk membelikan kebutuhannya seperti rokok dan pulsa serta menanggung biaya hidupnya di akhir bulan. Kekerasan finansial juga dialami oleh Fressy dimana saat ia telah tinggal bersama dengan Gune, kebutuhan hidup dan kuliahnya masih ditanggung oleh orang Fressy. Gune yang telah bekerja, tidak pernah membantu ataupun memberikan uang satu rupiah pun kepada Gune. 


\section{Kekerasan Digital}

Bentuk kekerasan ini muncul dalam pengalaman Fressy, Jolly dan Sanadril yakni berupa upaya-upaya untuk mengontrol akun media sosial pasangan. Misalnya Jolly yang secara berkala mengecek kotak masuk media sosial Sanadril dan begitu pula sebaliknya. Sedangkan Fressy dan pasangannya Gune, saling menunjukkan kemarahan, membalas komentar dan bertengkar secara virtual di akun facebook. Untuk pengalaman Taro, ia bahkan memblokir Tingki dari akun facebook karena ia malu jika Tingki memperlihatkan kebersamaan mereka di media sosial. Sikap pengabaian Taro ini juga merupakan bentuk kekerasan karena Taro telah menolak Tingki (walau hanya) secara virtual.

\section{Kekerasan Seksual}

Bentuk kekerasan ini sangat terlihat jelas dari pengalaman Fressy. Dimana pemukulan dan penggunaan kata-kata kasar harus ia terima saat ia menolak diajak berhubungan seksual oleh pasangannya. Sedangkan dalam pengalaman Jolly dan Sanadril, pola yang sama muncul hanya saja pada saaat Sanadril dalam keadaan mabuk. Lalu untuk pengalaman Taro sendiri, tindakan memanfaatkan Tingki sebagai orang yang bisa diajak untuk tidur saja tanpa adanya rasa sayang bahkan sengaja dibiarkan merupakan bentuk subtil dari kekerasan seksual.

\section{Kesimpulan}

Dalam pacaran, kekerasan terjadi karena konsep cinta yang menjadi dasar hubungan pacaran disalahartikan baik oleh pelaku maupun korban. Cinta diterjemahkan pelaku sebagai kepemilikan dan kontrol sedangkan cinta versi korban adalah bertahan dan mengharapkan suatu hari korban berubah. Oleh sebab itu, kekerasan dalam pacaran hadir dikarenakan adanya pembiaran serta dipelihara baik pihak korban dan pelaku. Terutama dalam struktur hubungan dimana laki-laki sebagai pihak yang dominan, utama, subjek serta aktif dan sebaliknya perempuan sebagai pihak yang subordinat, kedua, objek serta pasif. Keberadaan budaya kekerasan dalam pacaran ini juga tidak bisa disangkal merupakan hasil dari budaya, pola didikan orang tua dan lingkungan tempat tinggal pelaku dan korban. Untuk pelaku pola didikan yang keras membuat pelaku juga menjadi keras. Kemudian 
Kisah Cinta Tidak Indah : Studi Kekerasan dalam Relasi Pacaran Mahasiswa di Fakultas Ilmu Sosial dan Ilmu Politik Universitas Cenderawasih Jayapura

untuk korban, keluarga yang baik dan harmonis namun tidak mengajarkan korban untuk belajar berani bersikap membuat korban menerima untuk mendapat perlakuan kekerasan bahkan memilih bertahan dalam siklus kekerasan. Dalam kalimat lain budaya yang memperlihatkan kekerasan dalam relasi laki-laki dan perempuan pada umumnya di Papua melanggengkan kekerasan dalam pacaran sebagai sesuatu yang normal atau wajar.

\section{Daftar Pustaka}

Asmarani D. 2015. Kekerasan dalam Pacaran Fenomena Sunyi di Indonesia (online), diunduh dari <https://www.rappler.com/world/regions/asiapacific/indonesia/94590-kekerasan-dalam-pacaran-indonesia>

Courtaina, A. dan Glowaczb, F. 2019. Measuring Dating Violence: Conflict or Non-Conflict Related Instructions?, Revue Européenne de Psychologie Appliquée (69), (1-8)

Eriyanti, L.D., 2017. Pemikiran John Galtung Tentang Kekerasan dalam Perspektif Feminisme. Jurnal Hubungan Internasional, 6(1), (27-37)

Khaninah, N. Anik \& Mochamad, Widjarnako. 2015. Perilaku Agresif yang Dialami Korban Kekerasan dalam Pacaran. Jurnal Psikologi Universitas Diponegoro 15(2), (151-160)

Kim, Y. dkk. 2019. Sexual Double Standard, Dating Violence Recognition, and Sexual Assertiveness among University Students in South Korea. Asian Nursing Research (13), (47-52)

Komnas Perempuan, 2018. Catatan Tahunan Komisi Nasional Perempuan Tahun 2017 dan 2018. Jakarta

Sari D. Kurnia, 2018. Kekerasan dalam Pacaran pada Ruang Akademik: Studi Kasus IAIN Tulung Agung. Martabat: Jurnal Perempuan dan Anak. 2(1), (51-70)

Yayasan Pulih, 2018. Kekerasan dalam Pacaran (online), <http://yayasanpulih.org/2018/01//kekerasan-dalam-pacaran/> 